Abstract-We describe the food habits of the Sowerby's beaked whale (Mesoplodon bidens) from observations of 10 individuals taken as bycatch in the pelagic drift gillnet fishery for Swordfish (Xiphias gladius) in the western North Atlantic and 1 stranded individual from Kennebunk, Maine. The stomachs of 8 bycaught whales were intact and contained prey. The diet of these 8 whales was dominated by meso- and benthopelagic fishes that composed $98.5 \%$ of the prey items found in their stomachs and cephalopods that accounted for only 1.5\% of the number of prey. Otoliths and jaws representing at least 31 fish taxa from 15 families were present in the stomach contents. Fishes, primarily from the families Moridae (37.9\% of prey), Myctophidae (22.9\%), Macrouridae (11.2\%), and Phycidae $(7.2 \%)$, were present in all 8 stomachs. Most prey were from 5 fish taxa: Shortbeard Codling (Laemonema barbatulum) accounted for $35.3 \%$ of otoliths, Cocco's Lanternfish (Lobianchia gemellarii) contributed $12.9 \%$, Marlin-spike (Nezumia bairdii) composed $10.8 \%$, lanternfishes (Lampanyctus spp.) accounted for $8.4 \%$; and Longfin Hake (Phycis chesteri) contributed $6.7 \%$. The mean number of otoliths per stomach was 1196 (range: 327-3452). Most of the fish prey found in the stomachs was quite small, ranging in length from 4.0 to $27.7 \mathrm{~cm}$. We conclude that the Sowerby's beaked whales that we examined in this study fed on large numbers of relatively small mesoand benthopelagic fishes that are abundant along the slope and shelf break of the western North Atlantic.

Manuscript submitted 4 February 2013. Manuscript accepted 30 August 2013. Fish. Bull. 111:381-389.

doi: 10.7755/FB.111.4.7

The views and opinions expressed or implied in this article are those of the author (or authors) and do not necesarily reflect the position of the National Marine Fisheries Service, NOAA.

\title{
Food habits of Sowerby's beaked whales (Mesoplodon bidens) taken in the pelagic drift gillnet fishery of the western North Atlantic
}

\author{
Frederick W. Wenzel (contact author) ${ }^{1}$ \\ Pamela T. Polloni ${ }^{2}$ \\ James E. Craddock² (deceased) \\ Damon P. Gannon ${ }^{3}$ \\ John R. Nicolas ${ }^{1}$ (deceased) \\ Andrew J. Read ${ }^{4}$ \\ Patricia E. Rosel ${ }^{5}$
}

Email address for contact author: frederick.wenzel@noaa.gov

\author{
1 Protected Species Branch \\ Northeast Fisheries Science Center \\ National Marine Fisheries Service, NOAA \\ 166 Water Street \\ Woods Hole, Massachusetts 02543 \\ 2 Biology Department \\ Woods Hole Oceanographic Institution \\ Woods Hole, Massachusetts 02543 \\ ${ }^{3}$ Department of Biology \\ Bowdoin College \\ 6500 College Station \\ Brunswick, Maine 04011
}

\author{
${ }^{4}$ Division of Marine Science and Conservation \\ Nicholas School of the Environment \\ Duke University \\ Beaufort, North Carolina 28516 \\ 5 Protected Resources and Biodiversity Division \\ Southeast Fisheries Science Center \\ National Marine Fisheries Service, NOAA \\ 646 Cajundome Blvd. \\ Lafayette, Louisiana 70506
}

The Sowerby's beaked whale (Mesoplodon bidens) is 1 of 4 species of the genus Mesoplodon (Family Ziphiidae) in the western North Atlantic. The Sowerby's beaked whale is restricted to the North Atlantic and the most boreal species in its genus, with observations recorded as far north as $71^{\circ} \mathrm{N}$ (Carlstrom et al., 1997; Hooker and Baird, 1999; McAlpine and Rae, 1999; Lucas and Hooker, 2000; Waring et al., 2010). There is also a single record of a stranded Sowerby's beaked whale from the Gulf of Mexico (Bonde and O'Shea, 1989).

Most information on the distribution and abundance of beaked whales off the northeastern coast of the United States has been derived from vessel surveys conducted by NOAA Fisheries. It is difficult to identify Mesoplodon beaked whales to species level at sea; therefore estimates of abundance are often reported at the generic level in stock assessments (e.g., Waring et al., 2010). Waring et al. (2001) reported that off the northeastern coast of the United States, Mesoplodon beaked whales were encountered most frequently along the shelf break and north wall of the Gulf Stream. The habitat preferences of these animals overlap with the habitat preferences of the sperm whale (Physeter macrocephalus), but Sowerby's beaked whales were concentrated on the colder shelf edge (Griffin, 1999; Waring et al., 2001).

MacLeod et al. (2003) reviewed available information on the diet of beaked whales and concluded that fishes are important prey of 5 of the 10 (Family Ziphiidae) species for which diet information was available. This conclusion stands in contrast to earlier reviews of the diet of beaked whales where the importance of squids was emphasized (e.g., Clarke, 1986). Beaked whales are cryptic, deep-diving odontocetes, and, 
as a result, direct observation of foraging is impossible. Most insight into their feeding behavior has come from digital acoustic tags, which record the 3-D movement and acoustic environment of tagged individuals (e.g., Madsen et al., 2005). Application of these tags to individuals of the Blainville's beaked whale (Mesoplodon densirostris) indicates that this species forages at depths of more than $1000 \mathrm{~m}$ in dives that may last for almost $1 \mathrm{~h}$ (Arranz et al., 2011). To date, however, no Sowerby's beaked whales have been studied with digital acoustic tags.

Given the challenges of studying live whales, all published information on the food habits of the Sowerby's beaked whale has been acquired from stranded specimens (Dix et al., 1986; Lien and Barry, 1990; Lien et al. 1990; Ostrom et al., 1993; Pereira et al., 2011; Spitz et al., 2011; Santos et al.1,2). Recent analysis of the stomach contents of 10 stranded Sowerby's beaked whales from the Azores in the eastern North Atlantic (Pereira et al., 2011) provided evidence that small meso- and bathypelagic fishes constitute an important part of the diet of this species in this area.

One largely untapped source of information on the biology of the Sowerby's beaked whale comes from a sample of animals taken as bycatch in a pelagic drift gillnet fishery for Swordfish (Xiphias gladius) that operated in the western North Atlantic between 1989 and 1998. The pelagic drift gillnet fishery was monitored by observers from the Northeast Fisheries Observer Program (NEFOP); these observers documented bycatch consisting of more than 1100 individuals of 14 marine mammal species (Waring et al., 2000). This bycatch included 46 beaked whales taken in the "northern or summer stratum" of the fishery that operated along the continental shelf break along the southern side of Georges Bank (Waring et al., 2009). Pelagic drift gillnets were prohibited after 1998 because of the large number of cetaceans taken during fishing operations that used them (Waring et al., 2000; 2002). Here, we describe the stomach contents of Sowerby's beaked whales taken in this pelagic drift net fishery, and we provide the first detailed account of the food habits of Sowerby's beaked whales from the western North Atlantic.

\section{Materials and methods}

We examined the stomach contents of 10 Sowerby's beaked whales taken incidentally in the pelagic drift gillnet fishery for Swordfish in the Atlantic between August 1989 and July 1996 and a single dead stranded

\footnotetext{
${ }^{1}$ Santos, M. B., G. J. Pierce, H. M. Ross, R. J. Reid, and B. Wilson. 1994. Diets of small cetaceans from the Scottish coast. ICES Council Meeting (C.M.) document, 1994/N:11. [Presented as a poster.]

2 Santos, M. B., G. J. Pierce, G. Wijnsma, H. M. Ross, and R. J. Reid. 1995. Diets of small cetaceans stranded in Scotland 1993-1995. ICES Council Meeting (C.M.) document, 1995/N:6.
}

individual from Kennebunk, Maine (Table 1 and Fig. 1). We obtained skin tissue from each bycaught specimen and conducted DNA analysis at the NOAA Southeast Fisheries Science Center to confirm that each animal was in fact a Sowerby's beaked whale. DNA was extracted from the tissue through the use of standard proteinase $\mathrm{K}$ digestion followed by organic extraction (Rosel and Block, 1996). The quality of the DNA was assessed through agarose gel electrophoresis, and DNA quantity was measured with a fluorometer (Amersham Biosciences $^{3}$, now GE Healthcare Life Sciences, Little Chalfont, UK).

To confirm field identifications on the basis of morphology, the 5'-end of the mitochondrial DNA control region was amplified and sequenced as described in Sellas et al. (2005). Resultant DNA sequences were identified to species through phylogenetic reconstruction with an alignment that contained the new control region sequences and the sequences obtained from the 5 species of beaked whales present in the western North Atlantic. Mesoplodont whales form strongly supported clades in phylogenetic analyses of control region sequences; therefore, this method is well suited to species identification of unknown samples (Henshaw et al., 1997; Dalebout et al., 2004).

The unusual stomach anatomy of beaked whales has been described in detail by Mead (1989, 1993, 2007). We examined the contents of the esophagus and upper digestive tract, including the fore stomach, main stomach, connecting chambers, and pyloric stomach. We followed a standard protocol for analysis of stomach contents (see Craddock et al., 2009), separating hard parts from the remaining digesta by elutriation and then decanting them through a sieve with a $0.5-\mathrm{mm}$ mesh. We then sorted, dried, and identified all hard parts to the lowest possible taxonomic level. Certain diagnostic bones of fishes (e.g., otoliths, dentaries, premaxillaries, and maxillaries) were stored separately from other hard parts. Squid beaks and all parasites were counted and preserved in $70 \%$ ethanol. We archived the contents of each stomach separately.

We identified the hard parts of prey items through the use of published guides (Roper et al., 1984; Clarke, 1986; Harkonen, 1986; Vecchione et al., 1989; Campana, 2004) and the otolith and skeletal bone reference collection prepared by J. E. Craddock at the Woods Hole Oceanographic Institution (WHOI). This collection is now part of the ichthyology collection of the Museum of Comparative Zoology, Harvard University, Cambridge, Massachusetts (http://www.mcz.harvard. edu/Departments/Ichthyology/researchcoll.html, accessed May 2013).

We estimated the number of fish prey using half the number of otoliths when more than 50 otoliths were present. When fewer than 50 otoliths were present, we

\footnotetext{
${ }^{3}$ Mention of trade names or commercial companies is for identification purposes only and does not imply endorsement by the National Marine Fisheries Service, NOAA.
} 
Table 1

Origin and description of Sowerby's beaked whales (Mesoplodon bidens) obtained in the western North Atlantic between August 1989 and October 2003. Most whales were retained as bycatch in the pelagic drift gillnet fishery for Swordfish (Xiphias gladius). One whale was collected stranded in Kennebunk, Maine. Latitudes and longitudes are given in decimal degrees. $\mathrm{NA}=$ not available; $\mathrm{M}=$ male; $\mathrm{F}=$ female.

\begin{tabular}{|c|c|c|c|c|c|c|c|c|c|c|}
\hline $\begin{array}{l}\text { Whale } \\
\text { identification }\end{array}$ & Latitude & Longitude & Depth (m) & Year & Month & Day & Source & Sex & Length $(\mathrm{cm})$ & $\begin{array}{l}\text { Wt. of } \\
\text { stomach } \\
\text { contents } \\
\text { (g) }\end{array}$ \\
\hline D00253 & 40.23 & 67.90 & 1050 & 1989 & 10 & 10 & Drift gillnet & M & 491 & 1816 \\
\hline D00341 & 40.02 & 68.80 & 1200 & 1995 & 6 & 24 & Drift gillnet & $\mathrm{F}$ & 485 & 5830 \\
\hline D01369 & 40.87 & 66.42 & 1600 & 1994 & 6 & 10 & Drift gillnet & M & 462 & 5897 \\
\hline D01380 & 40.97 & 66.32 & 1900 & 1994 & 6 & 3 & Drift gillnet & $\mathrm{F}$ & 460 & 4082 \\
\hline D03070 & 40.03 & 68.77 & 1350 & 1996 & 7 & 4 & Drift gillnet & $\mathrm{F}$ & 476 & 2700 \\
\hline D03202 & 40.35 & 67.35 & 1350 & 1996 & 7 & 6 & Drift gillnet & M & 470 & 2650 \\
\hline D03458 & 40.03 & 68.63 & 1600 & 1996 & 7 & 4 & Drift gillnet & $\mathrm{F}$ & 471 & NA \\
\hline D03486 & 40.97 & 66.40 & 750 & 1994 & 7 & 10 & Drift gillnet & $\mathrm{F}$ & 495 & 4082 \\
\hline D06061 & 40.78 & 66.57 & 1250 & 1990 & 8 & 9 & Drift gillnet & $\mathrm{F}$ & 274 & Empty \\
\hline F00120 & 40.87 & 66.48 & 1150 & 1989 & 8 & 26 & Drift gillnet & M & 473 & Partial \\
\hline MH03-604 & 43.33 & 70.52 & $\mathrm{NA}$ & 2003 & 10 & 2 & Stranding & M & 442 & Empty \\
\hline
\end{tabular}

counted the maximum number of either right or left otoliths for each fish species. We assessed relative prey importance by frequency of occurrence (FO) and proportion of numerical abundance $(\% \mathrm{~N})$. FO is the proportion of stomachs that contained a particular type of prey, $\% \mathrm{~N}$ is the proportion that each prey type represented of the total number of prey items recovered, and the minimum number of fish, is determined by the number of paired otoliths found in each stomach, with any odd numbered otolith raising the minimum number of fish by one (Table 2). We measured whole undigested otoliths from abundant fish prey with a stage micrometer or vernier calipers and estimated prey sizes with linear regressions derived from the WHOI reference collection (Table 3 ). We estimated the number of individual cephalopod prey from the maximum number of either upper or lower beaks (Table 4).

\section{Results}

One of the 10 stomachs which we examined was from a calf and contained only mucous or milk, and the stomach of the stranded individual was completely empty. In addition to the 10 stomachs examined for this study, another stomach was dissected and examined at sea by a NEFOP observer who retained only 14 otoliths: 9 Marlin-spike (Nezumia bairdii) and 5 Cocco's Lanternfish (Lobianchia gemellarii). Because of the incomplete examination of the stomach contents of this individual, we did not include it in the quantitative analysis of food habits. The remaining 8 stomachs were intact and contained prey; therefore we used the contents of these stomachs in our quantitative analysis of the frequency, numerical abundance, and size of prey. Genetic analysis confirmed that these stomachs were all from Sowerby's beaked whales.

Fishes dominated the diet of these whales; in total, we recovered 9451 otoliths of fishes and jaws of 18 Sloan's Viperfish (Chauliodus sloani). The only prey represented by more jawbones than otoliths was Sloan's Viperfish. The mean number of otoliths per stomach was 1196 (range: 327-3452). The recovered otoliths represented at least 31 species from 15 families of deepwater fishes (Table 2). Fishes from the families Moridae ( $\% \mathrm{~N}=37.9 \%$ of prey), Myctophidae (22.9\%), Macrouridae (11.2\%), and Phycidae $(7.2 \%)$ were present in all 8 stomachs. Most (74.1\%) prey were from the following 5 taxa, ordered by proportion of numerical abundance: 1) Shortbeard Codling (Laemonema barbatulum), Moridae, 35.3\%; 2) Cocco's Lanternfish, Myctophidae, $12.9 \%$; 3) Marlin-spike, Macrouridae, 10.8\%; 4) lanternfishes (Lampanyctus spp.), Myctophidae, 8.4\%; and 5) Longfin Hake (Phycis chesteri), Phycidae, $6.7 \%$. In each stomach, 12-19 different fish taxa were present, with a mean of 15 . The estimated standard lengths of fish prey ranged from $4.0 \mathrm{~cm}$ to $27.7 \mathrm{~cm}$ (Table 3). In its esophagus, whale D01380 had 13 whole Cocco's Lanternfish, ranging in length from 8.0 to 10.0 $\mathrm{cm}$ (mean: $9.2 \mathrm{~cm}$ ), similar to lengths of fish estimated from otoliths of this species found in the other 7 stomachs examined (Table 3 ).

Squid remains were found in 7 of the 8 analyzed stomachs, but they were represented by only 123 beaks (minimum 73 individuals) of 3 identified taxa (Table 4); cephalopods accounted for only $1.5 \%$ of total prey. The mean number of squid beaks per stomach was 15.4 (range: 0.0-35.0). 


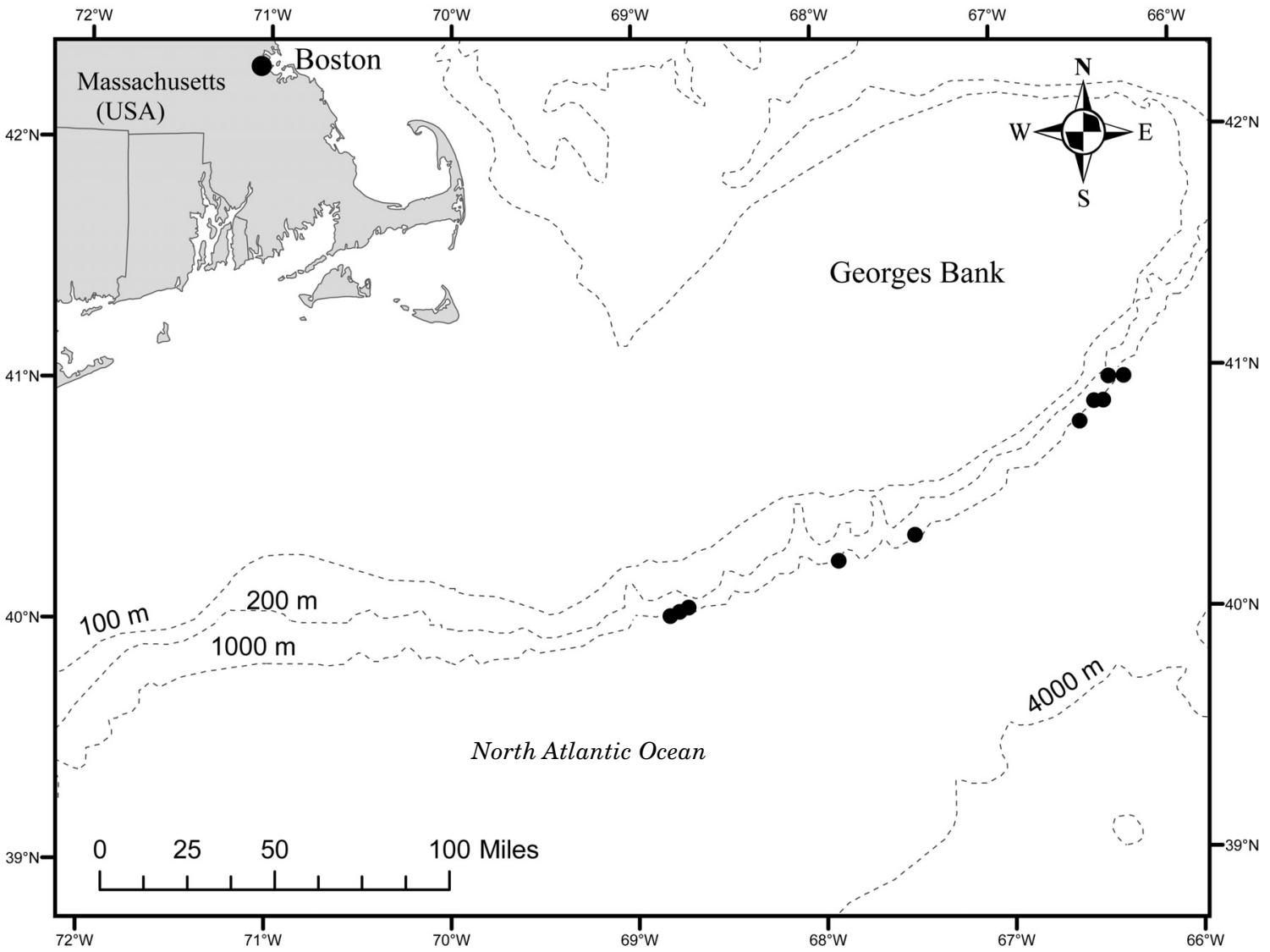

Figure 1

Map of locations where 10 specimens of the Sowerby's beaked whale (Mesoplodon bidens) were taken in the pelagic drift gillnet fishery for Swordfish (Xiphias gladius) in the western North Atlantic between August 1989 and July 1996. The stomach contents of 8 of these whales were examined to determine the food habits of this species.

\section{Discussion}

The Sowerby's beaked whales that we examined had been feeding primarily on large numbers of relatively small meso- and benthopelagic fishes before their death; cephalopod prey constituted a very minor part of the diet of these animals. Our findings are similar to those of Pereira et al. (2011), who examined the stomach contents of 10 stranded Sowerby's beaked whales from the Azores and found a predominance of small fish prey. It is important to note that all but one of the whales that we examined were killed at sea, and, with the exception of the single stranded animal, they were apparently healthy at the time of their death. The presence of intact prey in the esophagus of one specimen and the large numbers of prey items in the stomachs that we examined indicate that these animals had been foraging before death. The average minimum number of prey in the stomachs that we examined was more than 600 (4789 fishes, plus 73 squids, in all 8 stomachs combined), compared with 85 prey in the stranded specimens examined by Pereira et al. (2011).

We believe the stomach contents of the whales that we examined are representative of the summer diet of Sowerby's beaked whales along the continental shelf break off the northeastern coast of the United States. Nevertheless, biases from several sources could affect our conclusions. For example, our analysis of the stomach contents of these bycaught cetaceans could have been biased if these whales had been feeding in or around a fishing gear. Such behavior has not been reported for beaked whales, however, and the Sowerby's beaked whales that we examined were taken in pelagic drift gillnets that targeted large Swordfish and tunas in the top $10 \mathrm{~m}$ of the water column. These large-mesh gillnets could not have captured the prey we identified in stomachs of Sowerby's beaked whales; the only whole fish we recovered were 13 small $(<10.0 \mathrm{~cm})$ Cocco's Lanternfish found in one esophagus. Therefore, the Sowerby's beaked whales that we examined were not actively feeding in nets when captured. 


\section{Table 2}

Analysis of fish prey identified in stomachs of Sowerby's beaked whales (Mesoplodon bidens) taken in the pelagic drift gillnet fishery for Swordfish (Xiphias gladius) in the western North Atlantic between August 1989 and July 1996. \%FO= percentage of frequency of occurrence; $\% \mathrm{~N}=$ percentage of number of otoliths. Unidentified means that the structure of the otoliths was distinct for identification but the otoliths were not identified. Unidentifiable otoliths were worn or digested and not identifiable.

\begin{tabular}{|c|c|c|c|c|c|c|c|}
\hline Family & Species & Common name & $\begin{array}{l}\text { Occurrence } \\
\text { (no. of } \\
\text { stomachs) }\end{array}$ & $\% \mathrm{FO}$ & $\begin{array}{c}\text { Number } \\
\text { of } \\
\text { otoliths }\end{array}$ & $\% \mathrm{~N}$ & $\begin{array}{c}\text { Minimum } \\
\text { number } \\
\text { of fish }\end{array}$ \\
\hline Alepocephalidae & Alepocephalus cf. agassizii & Agassiz's Smoothhead & 4 & 50 & 10 & 0.1 & 6 \\
\hline Diretmidae & Diretmus argenteus & Spinyfin & 1 & 13 & 2 & 0.0 & 1 \\
\hline Gonostomatidae & Gonostoma elongatum & Longtooth Anglemouth & 2 & 25 & 6 & 0.1 & 4 \\
\hline Macrouridae & Coelorinchus sp. & Grenadier & 1 & 13 & 4 & 0.0 & 2 \\
\hline Macrouridae & Coryphaenoides sp. & Grenadier & 3 & 38 & 39 & 0.4 & 21 \\
\hline Macrouridae & Nezumia bairdii & Marlin-spike & 8 & 100 & 1019 & 10.8 & 515 \\
\hline Melamphaidae & Poromitra capito & Ridgehead & 1 & 13 & 3 & 0.0 & 2 \\
\hline Melamphaidae & Scopelogadus beanii & Bean's Bigscale & 7 & 88 & 344 & 3.6 & 178 \\
\hline Merlucciidae & Merluccius albidus & Offshore Hake & 1 & 13 & 1 & 0.0 & 1 \\
\hline Merlucciidae & Merluccius bilinearis & Silver Hake & 2 & 25 & 311 & 3.3 & 156 \\
\hline Moridae & Gadella imberbis & Beardless Codling & 3 & 38 & 65 & 0.7 & 33 \\
\hline Moridae & Laemonema barbatulum & Shortbeard Codling & 8 & 100 & 3332 & 35.3 & 1672 \\
\hline Moridae & Unidentified morid & Codling & 1 & 13 & 178 & 1.9 & 89 \\
\hline Myctophidae & Benthosema glaciale & Glacier Lanternfish & 3 & 38 & 5 & 0.1 & 3 \\
\hline Myctophidae & Bolinichthys supralateralis & Stubby Lanternfish & 1 & 13 & 2 & 0.0 & 1 \\
\hline Myctophidae & Ceratoscopelus maderensis & Horned Lanternfish & 7 & 88 & 75 & 0.8 & 40 \\
\hline Myctophidae & Hygophum hygomii & Bermuda Lanternfish & 4 & 50 & 6 & 0.1 & 4 \\
\hline Myctophidae & Lampadena speculigera & Mirror Lanternfish & 7 & 88 & 36 & 0.4 & 19 \\
\hline Myctophidae & Lampanyctus spp. & Lanternfishes & 8 & 100 & 797 & 8.4 & 403 \\
\hline Myctophidae & Lobianchia gemellarii & Cocco's Lanternfish & 8 & 100 & 1222 & 12.9 & 613 \\
\hline Myctophidae & Nannobrachium cf. atrum & Dusky Lanternfish & 5 & 63 & 15 & 0.2 & 8 \\
\hline Paralepididae & Arctozenus risso & White Barracudina & 8 & 100 & 90 & 1.0 & 49 \\
\hline Paralepididae & Unidentified paralepidid & & 2 & 25 & 4 & 0.0 & 2 \\
\hline Paralichthyidae & Paralichthys oblongus & Fourspot Flounder & 1 & 13 & 1 & 0.0 & 1 \\
\hline Phycidae & Phycis chesteri & Longfin Hake & 7 & 88 & 634 & 6.7 & 321 \\
\hline Phycidae & Urophycis chuss & Red Hake & 2 & 25 & 30 & 0.3 & 15 \\
\hline Phycidae & Urophycis tenuis & White Hake & 2 & 25 & 8 & 0.1 & 4 \\
\hline Scorpaenidae & Helicolenus dactylopterus & Blackbelly Rosefish & 7 & 88 & 350 & 3.7 & 179 \\
\hline Serrivomeridae & Serrivomer beanii & Stout Sawpalate & 1 & 13 & 3 & 0.0 & 2 \\
\hline Sternoptychidae & Polyipnus clarus & Slope Hatchetfish & 1 & 13 & 2 & 0.0 & 1 \\
\hline \multirow[t]{3}{*}{ Stomiidae } & Chauliodus cf. sloani & Sloan's Viperfish & 4 & 50 & 15 & 0.2 & 9 \\
\hline & & Unidentified otoliths & 8 & 100 & 215 & 2.3 & 114 \\
\hline & & Unidentifiable otoliths & 8 & 100 & 627 & 6.6 & 318 \\
\hline Total otoliths & & & & & 9451 & & \\
\hline Stomiidae & Chauliodus spp. & Viperfish jaws & 2 & 25 & 18 & & 3 \\
\hline Total fishes & & & & & & & 4789 \\
\hline
\end{tabular}

A second potential bias arises because hard parts of different prey may pass through the gastrointestinal tract at different rates. For example, squid beaks are resistant to digestion and often accumulate in stomachs of marine mammals, but the soft tissue and bones of fishes are more readily digested (Bigg and Fawcett, 1985). The complex structure of beaked whale stomachs (Mead 1989, 1993, 2007) makes it likely that relatively indigestible squid beaks are retained for prolonged periods. Therefore, the results reported here may overestimate the already low im- portance of cephalopods in the diet of the Sowerby's beaked whale.

A third possible bias arises from the secondary ingestion of prey, in which recovered hard parts enter whales in the stomachs of prey and are not consumed directly by whales themselves. It is difficult to evaluate this potential source of bias. It is possible, for example, that the Horned Lanternfish (Ceratoscopelus maderensis) we recovered could have been secondarily introduced into the stomachs of the Sowerby's beaked whales that we examined, given the small size of the 
Table 3

Habitat and size of the most abundant prey species found in stomachs of Sowerby's beaked whales (Mesoplodon bidens) taken in the pelagic drift gillnet fishery for Swordfish (Xiphias gladius) in the western North Atlantic between August 1989 and July 1996. Habitat/depths are taken from Fishbase (http://www.fishbase.org/search.php, accessed June 2013). Standard length was used to measure fish lengths. $R^{2}=$ coefficient of multiple determination; NA=not available

\begin{tabular}{|c|c|c|c|c|c|c|c|c|}
\hline Prey species & Habitat & $\begin{array}{l}\text { Diurnal } \\
\text { migrant }\end{array}$ & $\begin{array}{l}\text { Depth } \\
\text { range } \\
(\mathrm{m})\end{array}$ & $\begin{array}{l}\text { Number } \\
\text { measured }\end{array}$ & $\begin{array}{l}\text { Mean } \\
\text { otolith } \\
\text { length } \\
(\mathrm{cm})\end{array}$ & $\begin{array}{l}\text { Otolith } \\
\text { length } \\
\text { range } \\
(\mathrm{cm})\end{array}$ & $\begin{array}{l}\text { Otolith length } \\
\quad(\mathrm{OL})-\text { fish } \\
\text { length regression }\end{array}$ & $\begin{array}{l}\text { Mean length } \\
\text { of prey }(\mathrm{cm}) \\
\text { with range }\end{array}$ \\
\hline $\begin{array}{l}\text { Laemonema } \\
\text { barbatulum }\end{array}$ & Benthopelagic & No & $50-1620$ & 136 & 0.4 & $0.2-0.6$ & NA & NA \\
\hline $\begin{array}{l}\text { Lobianchia } \\
\text { gemellarii }\end{array}$ & Mesopelagic & Yes & $200-800$ & 140 & 0.7 & $0.6-0.8$ & $\begin{array}{c}\text { Fish length }= \\
0.0643 \mathrm{OL}+1.0482 \\
R^{2}=0.9799\end{array}$ & $9.7(8-11)$ \\
\hline $\begin{array}{l}\text { Nezumia } \\
\text { bairdii }\end{array}$ & Benthopelagic & No & $90-700$ & 198 & 0.8 & $0.5-1.0$ & $\begin{array}{c}\text { Fish length }= \\
0.035 \mathrm{OL}-0.0961 \\
R^{2}=0.9348\end{array}$ & $22(13-28)$ \\
\hline $\begin{array}{l}\text { Lampanyctus } \\
\text { spp. }\end{array}$ & Mesopelagic & Yes & $40-1000$ & 127 & 0.3 & $0.2-0.4$ & NA & NA \\
\hline Phycis chesteri & Benthopelagic & No & $90-1400$ & 74 & 1 & $0.6-1.3$ & NA & NA \\
\hline $\begin{array}{l}\text { Helicolenus } \\
\text { dactylopterus }\end{array}$ & Bathydemersal & No & $50-1100$ & 40 & 0.3 & $0.2-0.6$ & NA & NA \\
\hline $\begin{array}{l}\text { Scopelogadus } \\
\text { beanii }\end{array}$ & $\begin{array}{l}\text { Meso- to } \\
\text { bathypelagic }\end{array}$ & Yes & $400-1000$ & 38 & 0.3 & $0.2-0.4$ & $\begin{array}{c}\text { Fish length }= \\
0.0169 \mathrm{OL}+1.6267 \\
R^{2}=0.5816\end{array}$ & $8.1(5-11)$ \\
\hline $\begin{array}{l}\text { Arctozenus } \\
\text { risso }\end{array}$ & Mesopelagic & No & $200-1000$ & 43 & 0.4 & $0.3-0.4$ & $\begin{array}{c}\text { Fish length }= \\
0.0086 \mathrm{OL}+1.6552 \\
R^{2}=0.8359\end{array}$ & $21.5(10-27)$ \\
\hline $\begin{array}{l}\text { Ceratoscopelus } \\
\text { maderensis }\end{array}$ & Mesopelagic & Yes & $330-600$ & 24 & 0.3 & $0.2-0.3$ & $\begin{array}{c}\text { Fish length }= \\
0.0511 \text { OL }-0.1393 \\
R^{2}=0.9454\end{array}$ & $5.4(4-6)$ \\
\hline
\end{tabular}

fish we recovered $(4.0-6.3 \mathrm{~cm})$ and their low numbers. This fish species is generally abundant and found in schools in the deep scattering layer (DSL) along the shelf break on the southern side of Georges Bank (Backus et al., 1968) where the Sowerby's beaked whales that we examined were taken.

The mechanisms by which the Sowerby's beaked whale locates and captures prey are largely unknown. All whales in the genus Mesoplodon have relatively small mouths and few teeth, and they are believed to employ suction while feeding (Mead et al. 1982; Heyning and Mead, 1996). The Sowerby's beaked whale has 2 teeth that erupt only in sexually mature males (Mead, 1989; Heyning and Mead, 1996). The relatively small mouth and 2 teeth of this species may explain why Sowerby's beaked whales typically are found to have only small prey items in their stomachs.

Studies that employed digital acoustic tags on other beaked whales in this genus have provided brief but exceptionally rich glimpses into the foraging behavior of these animals. For example, tagged Blainville's beaked whales in the Canary Islands have been reported to feed on prey in the lower part of the DSL and within the benthopelagic zone (Arranz et al., 2011). Almost half of the attempts at prey capture made by these whales in the Canary Islands occurred in the benthic boundary layer, reinforcing the importance of benthopelagic prey for them. In addition, these Blainville's beaked whales appeared to focus on the oxygen minimum layer just below the DSL in areas of steep topography. Johnson et al. (2008) described the behavior of a tagged Blainville's beaked whale in the Bahamas that appeared to provoke a schooling reaction in mesopelagic prey that resulted in a school of prey up to $4 \mathrm{~m}$ in diameter and created an opportunity for the whale to more easily capture those prey. Until a tag is deployed for the deep-diving Sowerby's beaked whale, we can only speculate about the foraging behavior of 


\section{Table 4}

Cephalopod prey from the stomachs of Sowerby's beaked whales (Mesoplodon bidens) taken in the pelagic drift gillnet fishery for Swordfish (Xiphias gladius) in the western North Atlantic between August 1989 and July 1996. \%N=percentage of number of total beaks. $\% \mathrm{FO}=$ percentage of frequency of occurrence, on the basis of the number of stomachs studied.

\begin{tabular}{|c|c|c|c|c|c|c|c|c|c|c|c|}
\hline Prey item & D00253 & D00341 & D01369 & D01380 & D03070 & D03202 & D03458 & D03486 & Total & $\% \mathrm{~N}$ & $\% \mathrm{FO}$ \\
\hline Unidentified upper beaks & & 0 & 2 & 2 & 4 & 10 & 19 & 12 & 49 & 39.8 & 87.5 \\
\hline Unidentified lower beaks & & 0 & & & 5 & 8 & 16 & & 29 & 23.6 & 50.0 \\
\hline Histioteuthis spp. & 4 & & 13 & 7 & & & & 9 & 33 & 26.8 & 50.0 \\
\hline Taonius pavo & 9 & & & & & & & 2 & 11 & 8.9 & 25.0 \\
\hline Chiroteuthis veranyi & 1 & & & & & & & & 1 & 0.8 & 12.5 \\
\hline Total beaks & 14 & 0 & 15 & 9 & 9 & 18 & 35 & 23 & $\begin{array}{r}123 \\
72\end{array}$ & 100.0 & \\
\hline Total cephalopods & & & & & & & & & 73 & & \\
\hline
\end{tabular}

this species, but the results presented here indicate that their hunting strategies may be similar to those of their better-studied congener.

Therefore, on the basis of knowledge of the habitat preferences of prey recovered from the stomachs of Sowerby's beaked whales, we conclude that these animals feed in the meso- and benthopelagic environments along the shelf break, foraging in the water column and near the seafloor. Mesopelagic fishes in this region are important prey for several other cetacean species. Horned Lanternfish, in particular, is consumed by the Atlantic white-sided dolphin (Lagenorhynchus acutus) (Craddock et al., 2009) and by the common dolphin (Delphinus delphis), both of which are also caught incidentally in the pelagic drift gillnet fishery for Swordfish in the Atlantic (Craddock and Polloni ${ }^{4}$ ). The stomach of a harbor porpoise (Phocoena phocoena), captured in a pelagic drift net fishery off North Carolina was found to contain more than 1900 otoliths of Horned Lanternfish (Read et al., 1996).

Many marine organisms are concentrated in oceanographic frontal zones, as a result of increased production and advection (Jahn and Backus, 1976; Backus et al., 1977; Olson and Backus, 1985). As a consequence of these aggregations, predators (including swordfish) and fishermen exploit fronts. The mosaic of oceanic fronts associated with the Gulf Stream and its warm- and cold-core rings have long been targeted by fishermen of Swordfish, particularly along the shelf break (Smith et al., 1996). Swordfish have been reported to feed on some of the same prey items that we recovered from

\footnotetext{
${ }^{4}$ Craddock J. E., and P. T. Polloni. 2005. Food habits of small marine mammals from the Gulf of Maine and from slope water off the northeast US coast. Year 3, Final Report, revised, 31 p. Request no. EA 133F-02-RQ-0081. Requisition no. NFFM7320-2-15375. [Available from Northeast Fisheries Science Center, National Marine Fisheries Service, NOAA, 166 Water St., Woods Hole, MA 02543 http://www. nefsc.noaa.gov/publications/reports/EA133F02RQ0081.pdf.]
}

Sowerby's beaked whales (Scott and Tibbo, 1968; Stillwell and Kohler, 1985).

For example, barracudinas (Paralepididae) are important food items for Swordfish in the northwestern Atlantic (Scott and Tibbo, 1968) and were common prey of the Sowerby's beaked whales that we examined; White Barracudina (Arctozenus risso) is the most common barracudina in this region (Moore et al., 2003). Lanternfishes (Myctophidae) also are consumed by Swordfish in large numbers, but, because of their relatively small size, they do not contribute significantly to the mass ingested by these predators (Scott and Tibbo, 1968). The pelagic drift gillnet fishery in the Atlantic targeted Swordfish and tunas, and the fishing effort focused on thermal fronts along the shelf break, as described by Podesta et al. (1993). Therefore, the common prey fields and habitats of Swordfish and Sowerby's beaked whales may help to explain the relatively high bycatch rates of Sowerby's beaked whales in this fishery.

\section{Conclusions}

The diet of Sowerby's beaked whales in the western North Atlantic is dominated by meso- and benthopelagic fishes (98.5\%), and cephalopods accounted for only $1.5 \%$ of their prey. Future research with digital acoustic tags would be helpful to examine the diving and echolocation behavior of Sowerby's beaked whales in relation to the vertical and horizontal distribution of prey. A study that combines both the tagging methods used by Arranz et al. (2011) and survey data of the prey field documented with the use of scientific echosounders and by direct capture of voucher specimens would be particularly profitable. The regular occurrence of Sowerby's beaked whales in and near the canyons on the southern margin of Georges Bank, where the whale specimens we studied were captured, offers a promising field opportunity for such research. 


\section{Acknowledgments}

We dedicate this paper to the memory of coauthors James Craddock and John Nicolas, who were instrumental in this study. We thank J. Galbraith, T. Sutton, and the Northeast Fisheries Science Center for providing fish specimens to add to the reference collection; E. Josephson and H. J. Foley for providing maps; B. Hayward and M. Moore for assistance with sorting stomach contents; K. Hartel and C. Kenaley of the Museum of Comparative Zoology, Harvard University, for reference material and additional otolith measurements. We also recognize K. Hartel, D. Waples, F. Serchuk, M. Simpkins, G. Waring, and T. Fenster and 3 anonymous reviewers for the useful comments that helped to improve this manuscript. Our work was made possible by the dedication of observers from NEFOP and the cooperation of pelagic drift net fishermen. We thank our colleagues aboard the Abel-J for their assistance in the field. This work was funded by the Northeast Fisheries Science Center, Woods Hole, Massachusetts.

\section{Literature cited}

Arranz, P., N. Aguilar de Soto, P. T. Madsen, A. Brito, F. Bordes, and M. P. Johnson.

2011. Following a foraging fish-finder: diel habitat use of Blainville's beaked whales revealed by echolocation. PLoS ONE 6(12):e28353. doi:10.1371/journal. pone.0028353.

Backus, R. H., J. E. Craddock, R. L. Haedrich, and B. H. Robison.

1977. Atlantic mesopelagic zoogeography. In Fishes of the Western North Atlantic, part 7. (R. H. Gibbs, ed.), p. 266-287. Foundation Mar. Res., Yale Univ., New Haven, CT.

Backus, R. H., J. E. Craddock, R. L. Haedrich, D. L. Shores, J.

M. Teal, A. S. Wing, G. W. Mead, and W. D. Clarke.

1968. Ceratoscopelus maderensis: peculiar sound-scattering layer identified with this myctophid fish. Science 160:991-993.

Bigg, M. A., and I. Fawcett.

1985. Two biases in diet determination of northern fur seals (Callorhinus ursinus). In Marine mammals and fisheries. (J. R. Beddington, R. J. H. Beverton, and D. M. Lavigne, eds), p. 284-291. George Allen \& Unwin, Ltd., London.

Bonde, R. K., and T. J. O'Shea.

1989. Sowerby's beaked whale (Mesoplodon bidens) in the Gulf of Mexico. J. Mammal. 70:447-449.

Campana, S.

2004. Photographic atlas of fish otoliths of the northwest Atlantic Ocean, 284 p. Can. Spec. Publ. Fish. Aquat. Sci. 133.

Carlstrom, J., J. Denkinger, P. Feddersen, and N. Oien.

1997. Record of a new northern range of Sowerby's beaked whale (Mesoplodon bidens). Polar Biol. 17:459-461.

Clarke, M. R.

1986. A handbook for the identification of cephalopod beaks, 273 p. Oxford Univ. Press, Oxford.
Craddock, J. E., P. T. Polloni, B. Hayward, and F. Wenzel. 2009. Fishes and cephalopods in the diet of Atlantic white-sided dolphins (Lagenorhynchus acutus) off the coast of New England. Fish. Bull. 107:384-394.

Dalebout, M. L., C. S. Baker, J. G. Mead, V. G. Cockcroft, and

T. K. Yamada.

2004. A comprehensive and validated molecular taxonomy of beaked whales, family Ziphiidae. J. Hered. 95:459-473.

Dix, L., J. Lien, and D. E. Sergeant.

1986. A North Sea beaked whale, Mesoplodon bidens, in Conception Bay, Newfoundland. Can. Field-Nat. 100:389-391.

Griffin, R. B.

1999. Sperm whale distributions and community ecology associated with warm-core ring off Georges Bank. Mar. Mamm. Sci. 15:33-51.

Harkonen, T.

1986. Guide to the otoliths of the bony fishes of the Northeast Atlantic, 256 p. Danbiu ApS, Biological Consultants, Hellerup, Denmark.

Henshaw, M. D., R. G. LeDuc, S. J. Chivers, and A. E. Dizon. 1997. Identifying beaked whales (Family Ziphiidae) using mtDNA sequences. Mar. Mamm. Sci. 13:487-495.

Heyning, J. E., and J. G. Mead.

1996. Suction feeding in beaked whales: morphological and observational evidence. Nat. Hist. Mus. Los Ang. Cty. Contrib. Sci. 464, 12 p.

Hooker, S. K., and R. W. Baird.

1999. Observations of Sowerby's beaked whale, Mesoplodon bidens in the Gully, Nova Scotia. Can. Field-Nat. 113:273-277.

Jahn, A. E., and R. H. Backus.

1976. On the mesopelagic faunas of the Slope Water, Gulf Stream, and northern Sargasso Sea. Deep Sea Res. 23:223-234.

Johnson, M., L. S. Hickmott, N. Aguilar Soto, and P. T. Madsen. 2008. Echolocation behaviour adapted to prey in foraging Blainville's beaked whale (Mesoplodon densirostris). Proc. R. Soc. Lond., Ser. B: Biol. Sci. 275:133-139.

Lien, J., and F. Barry.

1990. Status of Sowerby's Beaked Whale, Mesoplodon bidens, in Canada. Can Field-Nat. 104:125-130.

Lien, J., F. Barry, K. Breeck, and U. Zuschlag.

1990. Multiple strandings of Sowerby's Beaked Whale, Mesoplodon bidens, in Newfoundland. Can. Field-Nat. 104:414-420.

Lucas, Z. N., and S. K. Hooker.

2000. Cetacean strandings on Sable Island, Nova Scotia, 1970-1998. Can. Field-Nat. 114:45-61.

MacLeod, C. D., M. B. Santos, and G. J. Pierce.

2003. Review of data on diets of beaked whales: evidence of niche separation and geographic separation. J. Mar. Biol. Assoc. U.K. 83:651-665.

Madsen, P. T., M. Johnson, N. Aguilar de Soto, W. M. X. Zimmer, and P. Tyack.

2005. Biosonar performance of foraging beaked whales (Mesoplodon densirostris). J. Exp. Biol. 208:181-194.

McAlpine, D. F., and M. Rae.

1999. First confirmed reports of beaked whales, cf. Mesoplodon bidens and $M$. densirostris (Ziphiidae), from New Brunswick. Can. Field-Nat. 113:293-295. 
Mead, J. G.

1989. Beaked whales of the genus Mesoplodon. In Handbook of marine mammals, vol. 4: river dolphins and the larger toothed whales (S. H. Ridgway and R. Harrison, eds.), p. 349-430. Academic Press, San Diego, CA.

1993. The systematic importance of stomach anatomy in beaked whales. Int. Mar. Biol. Res. Inst. [Japan] IBI Reports 4:75-86.

2007. Stomach anatomy and use in defining systemic relationships of the Cetacean Family Ziphiidae (beaked whales). Anat. Rec. 290:581-595.

Mead, J. G., W. A. Walker and W. J. Houck.

1982. Biological observations on Mesoplodon carlhubbsi (Cetacea: Ziphiidae). Smithsonian Contributions to Zoology 344:iii + 1-25.

Moore, J. A., K. E. Hartel, J. E. Craddock, and J. K. Galbraith. 2003. An annotated list of deepwater fishes from off the New England Region with new area records. Northeast. Nat. 10:159-248.

Olson, D. B., and R. H. Backus.

1985. The concentrating of organisms at fronts: a coldwater fish and a warm-core Gulf Stream ring. J. Mar. Res. 43:113-137.

Ostrom, P. H., J. Lien, and S. A. Macko.

1993. Evaluation of the diet of the Sowerby's beaked whale, Mesoplodon bidens, based on isotopic comparisons among northwestern Atlantic cetaceans. Can. J. Zool. 71:858-861.

Pereira, J. N., V. C. Neves, R. Prieto, M. A. Silva, I. Cascao,

C. Oliveira, M. J. Cruz, J. V. Medeiros, J. P. Barreiros, F. M.

Porteiro, and D. Clarke.

2011. Diet of mid-Atlantic Sowerby's beaked whales, $M e$ soplodon bidens. Deep Sea Res. (I Oceanogr. Res. Pap.) 58:1084-1090.

Podestá, G. P., J. A. Browder, and J. J. Hoey.

1993. Exploring the association between swordfish catch rates and thermal fronts on U.S. longline grounds in the western North Atlantic. Cont. Shelf Res. 13:253-277.

Read, A. J., J. R. Nicolas, and J. E. Craddock.

1996. Winter capture of a harbor porpoise in a pelagic drift net off North Carolina. Fish. Bull. 94:381-383.

Roper, C. F. E., M. J. Sweeney, and C. E. Nauen.

1984. FAO species catalogue. Vol. 3. Cephalopods of the world. An annotated and illustrated catalogue of species of interest to fisheries. FAO Fish. Synop. 125, vol. 3, 277 p. FAO, Rome.

Rosel, P. E., and B. A. Block.

1996. Mitochondrial control region variability and global population structure in the swordfish, Xiphias gladius. Mar. Biol. 125:11-22.
Scott, W. B., and S. N. Tibbo.

1968. Food and feeding habits of swordfish, Xiphias gladius, in the western North Atlantic. J. Fish. Res. Board Can. 25:903-919.

Sellas, A. B., R. S. Wells, and P. E. Rosel.

2005. Mitochondrial and nuclear DNA analyses reveal fine scale geographic structure in bottlenose dolphins (Tursiops truncatus) in the Gulf of Mexico. Conserv. Genet. 6:715-728.

Smith, T. D., R. B. Griffin, G. T. Waring, and J. G. Casey.

1996. Multispecies approaches to management of large marine predators. In The Northeast Shelf ecosystem: assessment, sustainability, and management (K. Sherman, N. A. Jaworski and T. J. Smayda, eds.), p. 467-490. Blackwell Science, Cambridge, MA.

Spitz, J., Y. Cherel, S. Bertin, J. Kiszka, A. Dewez, and V. Ridoux.

2011. Prey preferences among the community of deepdiving odontocetes from the Bay of Biscay, Northeast Atlantic. Deep Sea Res. (I Oceanogr. Res. Pap.) 58:273-282.

Stillwell, C. E., and N. E. Kohler.

1985. Food and feeding ecology of the swordfish Xiphias gladius in the western North Atlantic Ocean with estimates of daily ration. Mar. Ecol. Prog. Ser. 22:239-241.

Vecchione, M., C. F. E. Roper, and M. J. Sweeney.

1989. Marine flora and fauna of the eastern United States: Mollusca: Cephalopoda. NOAA Tech. Rep. NMFS 73, $23 \mathrm{p}$.

Waring, G. T., T. Hamazaki, D. Sheehan, G. Wood, and S. Baker 2001. Characterization of beaked whale (Ziphiidae) and sperm whale (Physeter macrocephalus) summer habitat in shelf-edge and deeper waters off the Northeast U.S. Mar. Mamm. Sci. 17:703-717.

Waring, G. T., E. Josephson, K. Maze-Foley, and P.E. Rosel (eds.).

2009. U.S. Atlantic and Gulf of Mexico marine mammal stock assessments-2009. NOAA Tech. Memo. NMFSNE-213, 528 p.

2010. U.S. Atlantic and Gulf of Mexico marine mammal stock assessments-2010. NOAA Tech. Memo. NMFSNE-219, 595 p.

Waring, G. T., J. M. Quintal, and C. P. Fairfield (eds.). 2002. U.S. Atlantic and Gulf of Mexico marine mammal stock assessments-2002. NOAA Tech. Memo. NMFSNE-169, $318 \mathrm{p}$.

Waring G. T., J. M. Quintal, and S. L. Swartz (eds.). 2000. U.S. Atlantic and Gulf of Mexico marine mammal stock assessments-2000. NOAA Tech. Memo. NMFSNE-162, 298p. 